\title{
2011 Yılı Kobi Mali Destek Programı Yararlanıcıların Etki Değerlendirmesi: TRA1 Bölgesi Analizi
}

\section{Dr. Öğretim Üyesi Zülküf Ayrangö1 ${ }^{{ }^{*}}$ Fatih Akın}

Geliş tarihi: 05.11.2018

Kabul tarihi: 08.01.2019

\section{Atıf bilgisi:}

Uluslararası Bilimsel Araştırmalar Dergisi (IBAD)

Cilt: $4 \quad$ Sayı: 1

Sayfa: $34-49$ Yıl: 2019

Dönem: Kış

This article was checked by Turnitin. Similarity Index 10\%

\footnotetext{
${ }^{1}$ Erzincan Binali Yıldırım Üniversitesi, Iktisat Bölümü, zulkufayrangol@gmail.com ORCID ID 0000-0003-4792-8634

${ }^{2}$ İnönü Üniversitesi, İktisat ABD Doktora Öğrencisi, akinfatih29@gmail.com ORCID ID 0000-0002-7741-4004

* Sorumlu yazar
}

ÖZ

$\mathrm{Bu}$ çalışmanın genel amacı; Kuzeydoğu Anadolu Kalkınma Ajansı (KUDAKA) tarafindan 2011 yılında uygulanan KOBİ Mali Destek Programı kapsamında sağlanan mali desteklerin değerlendirmesini yapmaktır. Bir saha araștırmasına dayanan çalışmanın özel amacı ise; 2011 yılında ajanstan destek almaya hak kazanmış ve proje uygulama süreçleri sona ermiş olan, Erzurum, Erzincan ve Bayburt illerinde uygulanmıs projelerin istihdam, üretim, yatırım, pazarlama ve bölgesel kalkınmanın diğer unsurlarına ilişkin etki ve sonuçlarını ve Kuzeydoğu Anadolu Kalkınma Ajansı'nın proje uygulama süreçlerini değerlendirmektir. Çalışmanın sonucunda 2011 yılında KOBİ Mali Destek Programı kapsamında destek alan ișletmelerin; üretim miktarında artış olduğu, ürünlerini sattıkları pazar büyüklüğünde artış olduğu ve istihdam sağladığı görülmektedir.

Anahtar Kelimeler: KOBİ, Bölgesel Kalkınma, Bölgesel Kalkınma Ajansı, Kuzeydoğu Anadolu Kalkınma Ajansı, Mali Destek Programı 


\section{Evaluation of The Efficiency Of SME Financial Support Program Of 2011: TRA1 Region} Analysis

\section{Asst. Prof. Dr Zülküf Ayrangöl ${ }^{*}$ Fatih Akin ${ }^{2}$}

First received: 05.11 .2018

Accepted: 09.01.2019

\section{Citation:}

Journal of the International

Scientific Research (IBAD)

Volume: 4 Issue: 1

Pages: 34-49 Year: 2019

Session: Winter

This article was checked by Turnitin. Similarity Index 10\%

${ }^{1}$ Erzincan Binali Yildırım University, Department of Economics, zulkufayrangol@gmail.com ORCID ID 0000-0003-4792-8634 2İnönü Universitiy, Department of Economics, PhD Student, akinfatih29@gmail.com

ORCID ID 0000-0002-7741-4004

* Corresponding Author

\begin{abstract}
The general purpose of this study is to evaluate the financial support provided by the Northeast Anatolia Development Agency (KUDAKA) in 2011 under the SME Financial Support Program. Based on a field study, the special purpose of this work is to examine the results and effects of the projects implemented in the Erzurum, Erzincan and Bayburt provinces, which have been awarded the Agency's support in 2011 and whose project implementation processes have come to an end (i.e., on employment, production, investment, marketing and other elements of regional development and the project implementation of Northeast Anatolia Development Agency processes). Results show that the enterprises that received support under the SME Financial Support Program in 2011 had an increase in the amount of production, in the market size of the products they sell, and employment.
\end{abstract}

Keywords: SME, Regional Development, Regional Development Agent, Northeast Anatolia Development Agency, Financial Support Program 


\section{Gİiș}

Dünyada meydana gelen ekonomik gelişmeler sonucunda ortaya çıkan yeni kalkınma stratejileri ve uygulamaları ülkeler arasındaki gelişmişlik farklarını giderek artırmakla kalmayıp, aynı zamanda ülkelerin kendi içindeki bölgesel gelişmişlik farklarının da artmasına neden olmuştur.

Ülkelerin hızla büyüme ve kalkınmaları için uyguladıkları ekonomi politikaları ülkeler arasındaki rekabetin büyümesine ortam hazırlamıștır. Bu büyüyen rekabet ortamında avantaj sağlamak isteyen ülkeler kendi içindeki bölgesel kalkınmışlık farklarını en aza indirmek için çeşitli ekonomik kalkınma planları uygulamak zorunda kalmışlardır.

Dünyada ilk kez 1930'lu yıllarda Amerika Birleşik Devletleri (ABD) tarafindan ülkedeki gelişmemiş bölgeleri kalkındırmak ve gelişmiş bölgelerle arasındaki farkları ortadan kaldırmak için bölgesel kalkınma planları hazırlanmıştır. Avrupa Birliği'nde ise 1950'li yıllardan itibaren kurulmaya başlayan bölgesel kalkınma ajansları, günümüzde çok önemli kurum ve kuruluşlar haline gelmiştir. Aynı zamanda ülkelerin bölgesel kalkınmaya yönelmelerinin nedeni; uluslararası desteklerden yardım alabilmektir. Gelişmekte olan ülkeler; özellikle bu rekabet ortamında başarılı sonuçlara ulaşmak için, mevcut durumlarını daha iyi yönetmeye çalışmaktadırlar.

20. Yüzyılda dünyada, 1980 sonrasında da ülkemizde benimsenen serbest piyasa ekonomisi anlayışı, gittikçe serbestleşen dünya ticareti ve küreselleşme ile birlikte bölgesel kalkınma ajanslarını daha da önemli hale getirmiştir. Ülkemizdeki bölgesel kalkınma ajansları; kalkınmanın bölgeler arasında eşit bir şekilde yayılmasına, kurumlar arası işbirliği ve iletişim ağlarının kurulması, yaygın hale getirilmesi ve özellikle ekonomik kalkınmanın sürekliliğini sağlamak için 2006 yılında "5449 sayılı Kalkınma Ajanslarının Kuruluşu, Koordinasyon ve Görevleri Hakkında Kanun', çerçevesinde kurularak yürürlüğe girmiştir.

Yürürlüğe giren bu kanun ile kalkınma ajansları; kurulduğu bölgedeki üniversiteleri, özel kurum ve kuruluşları, sivil toplum kuruluşları ve kamu kurumları arasındaki işbirliğini geliştirerek bölgenin kalkınmasını hedeflemiştir.

Bu çalışmada; Kuzeydoğu Anadolu Kalkınma Ajansı (KUDAKA) tarafindan 2011 yılında KOBİ'lere (Küçük ve Orta Büyüklükteki İşletmeler) verilen Mali Destek Programlarının (MDP) etki değerlendirme analizi yapılacaktır.

\section{Bölgesel Kalkınma ve Bölgesel Kalkınma Ajansı Kavramı}

Bölgesel Kalkınma kavramının çok eskiye dayanan bir geçmişi bulunmamaktadır. Kalkınma ekonomisin ortaya çıkması ile bölge ve kalkınma kavramları 1940'lardan itibaren birlikte kullanılmaya başlanılmıştır (Gök, 2004, s. 76). Bölgesel Kalkınma; dünyanın herhangi bir yerinde bulunan bir bölgenin, çevresindeki bölgeler ve dünyada bulunan diğer ülkeler arasında işbirliğini sürdürerek bulunduğu bölgenin gelişmesini sağlayan, bölgenin refahının artmasını hedefleyen çalışmaların tamamı olarak tanımlanmaktadır (Akpınar, Taşcı ve Özsan, 2011, s. 417-445).

OCED (Ekonomik İşbirliği ve Kalkınma Teşkilatı), Dünya Bankası, Birleşmiş Milletler (BM) gibi küresel kuruluşlar, akademisyen ve uygulamacılar arasında kabul gören tanıma göre ise Bölgesel Kalkınma; "sınırları belli bir bölgenin kapasitesini arttırmak, bölgede yaşayanların yaşam kalitelerini ve ekonomik geleceklerini iyileştirmek" şeklindeki tanım bugün kabul görmektedir (Aydemir, Karakoyun, 2011, s. 11). Verilen tanımlardan da anlaşılacağı üzere bölgesel kalkınmanın temel hedefi; bir bölgenin refahının arttırılması ve sürekliliğinin devam ettirilmesidir.

Bölgesel Kalkınma Ajansı kavramına ise ilk kez Amerika Birleşik Devletleri’nde (ABD) bulunan Tennessee'de 1930 yılında rastlanılmıştır (Sakal, 2010, s. 159). Temel kaynaklara bakıldığında Bölgesel Kalkınma Ajanslarına farklı açılardan, farklı bakış açılarıyla tanımlamalar yapıldığı görülmektedir.

EURADA (Avrupa Bölgesel Kalkınma Ajansları Birliği) tanımına göre Bölgesel Kalkınma Ajansları; "'Yerel ve bölgesel kurumlar arasında yönetim, gelirler, maliyetler ve görevler hakkında işbirliği yaparak örgütlenen kurumlar" olarak tanımlamıştır (Tuncel ve Bakir, 2010, s. 19-41). 
Dünya Bankası'nın tanımına göre Bölgesel Kalkınma Ajansları; “asıl amacı istihdam oluşturmak, üretimin çeşitli bölümlerinde bulunan KOBI'leri (Küçük ve Orta Büyüklükteki İşletmeler) geliştirip desteklemek ve bölgenin genel ekonomik durumunu ve ele geçen firsatları değerlendirerek, kalkınmayı sürdürebilecek içsel ağları kuran, yürüten ve destekleyen kuruluşlardır' diye tanımlamıştır (Çakmak, 2006, s. 64).

\section{Bölgesel Kalkınma Ajanslarının Tarihsel Gelişimi}

Bölgesel Kalkınma Ajansları; II. Dünya Savaşı'ndan önce ortaya çıkan kurum ve kuruluşlardır. Buna örnek verilecek olursa, 1930 yılında Bölgesel Kalkınma Ajanslarının ilk uygulaması Amerika Birleşik Devletleri'nin (ABD) güneyinde kurulan Tennessee Valley Authority'dir (TVA). Kurulan bu ajans bu bölgede bulunan kaynakların etkin ve verimli bir şekilde kullanılması, bölgenin ekonomik büyüme ve kalkınmasının artırmak ve diğer bölgeler arasındaki gelişmişlik farklarının azaltılması için yapılan bu uygulamada başarılı sonuçlar elde edilmiştir (Dinler, 1994, s. 309-310).

İkinci Dünya Savaşı sonrasında ise, ülkelerin kendi toprakları içerisinde bulunan bölgeler arasındaki gelişmişlik farklarının giderek artmaya başladığı bir dönem olmuştur. Bu gelişmeler sonucunda dünyada kalkınma ajansları daha çok kamuoyunda konuşulmaya başlanılmıştır. Bölgesel olarak ekonomik büyüme ve kalkınmanın İkinci Dünya Savaşı'ndan sonra önemi daha da arttığı için Bölgesel Kalkınma Ajansları ülkeler tarafindan daha çok bir politika aracı olarak kullanılmıștır. 1930'lu yıllardan itibaren dünyanın hemen hemen her bölgesinde kurulmaya başlayan Bölgesel Kalkınma Ajansları büyük çoğunluğu Avrupa kitasındadır (Özer, 2008, s. 389-408).

\section{ABD'de Bölgesel Kalkınma Ajanslarının Tarihsel Gelişimi}

1929 yılında Amerika Birleşik Devletleri'nde (ABD) ortaya çıkan ve tüm dünyayı etkisi altına alan “'Büyük Buhran'” ile ülkenin diğer bölgelerine göre, ülkenin güneyinde daha az gelişmiş olan Tennessee Vadisini gelişmesini sağlamak için 1930 yllında Tennessee Valley Authority (TVA) kurulduğuna değinilmişti. TVA'nın kurulmasındaki temel amaç; vadideki ekonomik yatırımları artırmaktır (Dinler, 2005, s. 208). Bölgede birçok baraj inşaatı inşa ederek, vadide bulunan sekiz eyalette yaşayan halka daha ucuza elektrik üretmek için TVA, bölgenin ekonomik büyümesi ve kalkınmasını sağlamada önemli rol oynamıştır (Dura, 2007, s. 141-171). 1960'lı yıllardan itibaren ABD’de Bölgesel Kalkınma Ajansları daha çok özel sektör ve kamu sektörünün bölgesel kalkınmayı, işbirliği içinde gerçekleştirmeyi amaçladığı yarı-özerk nitelikli oluşumlardır (Sert, 2012, s. 130).

$\mathrm{Bu}$ amaç doğrultusunda ABD'de kurulan bazı önemli ajanslar; ABD Uluslararası Kalkınma Ajansı (USAID), Yerel Yönetimler tarafindan kurulan kalkınma ajansları ve Mahalle Yönetimleri tarafından kurulan kalkınma ajanslarıdır.

\section{Avrupa'da Bölgesel Kalkınma Ajanslarının Tarihsel Gelişimi}

İkinci Dünya Savaşı'ndan sonra Avrupa Kıtasında bölgeler arası eşitsizlikler daha da artmaya başlamıştır. İtalya'da kuzey ve güney bölgesi arasındaki farklılıklar; Fransa'da Paris ve çevresinin ülkenin diğer bölgelerine göre daha çok gelişmesi; İngiltere, İskoçya ve Galler'in eski sanayilerinin çökmesiyle buraların yeniden inşa edilmesine gerek duyulması gibi etkenler, Avrupa ülkelerinde bölgesel kalkınma politikalarının uygulanmasına neden olmuştur (Akın ve Yıldız, 2005, s. 39).

Avrupa'nın batısında bölgesel farklılıkların derinleşmesiyle birlikte, bu ülkelerde de ajanslar kurulmaya başlamıştır. Batı Avrupa ülkelerinde bölgesel kalkınma ajanslarının kurulması, 1950'li yılları öncesine dayanmaktadır. Avrupa Birliği'nin kurulmasıyla birlikte, Orta ve Doğu Avrupa ülkelerinin gelişmesini sağlamak amaciyla 1990'lı yıllardan itibaren bu bölgelerde de ajanslar kurulmaya başlamıştır (Ö̈zen ve Özmen, 2010, s. 226-227).

Avrupa'da 1950'li yıllarda BKA'lar; Belçika, İrlanda, Avusturya ve Fransa'da, 1960-1970'li yıllarda; İngiltere, İtalya, Hollanda ve Almanya'da, 1980'li y1llarda; İspanya, Danimarka, Yunanistan ve Finlandiya'da kurulmuşlardır. 1990'lı yıllarda; Portekiz, Slovakya, Bulgaristan, Çek Cumhuriyeti, Estonya, Litvanya, Macaristan, İsveç, Ukrayna ve Polonya'da AB'nin isteği üzerine bu ülkelerde de kalkınma ajansları da kurulmaya başlamıştır (Sakal, 2010, s. 179; Özen, 2005, s. 4). 
Tablo 1: Avrupa Ülkelerinde Bölgesel Kalkınma Ajanslarının Kuruluş Yılları

\begin{tabular}{|c|c|c|c|}
\hline 1950'ler ve öncesi & 1960'lı ve 1970'li Yıllar & 1980'li Yıllar & 1990'lı Yillar \\
\hline $\begin{array}{l}\text { Avusturya } \\
\text { Belçika } \\
\text { Fransa } \\
\text { İrlanda }\end{array}$ & $\begin{array}{l}\text { Almanya } \\
\text { İngiltere } \\
\text { İtalya } \\
\text { Hollanda }\end{array}$ & $\begin{array}{l}\text { İspanya } \\
\text { Yunanistan } \\
\text { Finlandiya } \\
\text { Danimarka }\end{array}$ & $\begin{array}{l}\text { Bulgaristan } \\
\text { Çek Cumhuriyeti } \\
\text { Estonya } \\
\text { Macaristan } \\
\text { Litvanya } \\
\text { Polonya } \\
\text { Portekiz } \\
\text { Slovakya } \\
\text { Ukrayna } \\
\text { İsveç }\end{array}$ \\
\hline
\end{tabular}

Kaynak: (Özen ve Özmen, 2010, s. 257).

Avrupa'daki kalkınma ajanslarını kendi çatısı altında toplayarak hareket etmeyi hedefleyen EURADA (Avrupa Bölgesel Kalkınma Ajansları Birliği) 1991 yılında kurularak, faaliyete geçmiştir. EURADA'nın asıl amacı; AB'nin yatırımlarının danışmanlıklarını sürdürmek ve dünyadaki kalkınma ajansları ile AB'deki kalkınma ajansları arasında ortak işbirliği sağlamaktır (Cankorkmaz, 2011, s. 113-138).

\section{Türkiye'de Bölgesel Kalkınma Ajanslarının Tarihsel Gelişimi}

1950'li yıllardan itibaren AB ülkelerinde kurulmaya başlayan kalkınma ajansları, Türkiye'de 2000'li yıllarda Avrupa Birliğine girişs süreci ile düzenleme imkânı bulmuştur (Eren ve Cidecigiller, 2011, s. 396). AB ülkeleriyle karşılaştırma yapıldığında Türkiye, bölgesel olarak çok farklılık gösteren ve eşitsizliğe sahip olan ülke olarak görünmektedir (Koçberber, 2006, s. 37-55). Ülkemizde var olan bölgeler arası farklılıklar ve eşitsizlikler nedeniyle bölgesel planlama yapılması kaçınılmaz olmuştur.

Ülkemizde bölge planlaması çalışmaları ilk kez 1950'li yıllarda yapılmaya başlanmıştır. Bu çerçevede pilot bölgeler seçilmiş ve seçilen bölgelerle ilgili olarak sorunlar tespit edilmiş ve çözüm önerileri getirilmesi amaçlanmıştır (Taştekin, 2018, s. 73).

Bunlardan en önemlisi 1960 yılında kurulan Devlet Planlama Teşkilatı (DPT); ulusal düzeyde beş yıllık kalkınma planlamaları oluşturmaya başlamıştır. Aynı zamanda Bölgesel Kalkınma Planları (BKP), Yatırım Teşvikleri, Organize Sanayi Bölgeleri (OSB), Kırsal Kalkınma Projeleri (KKP), Kalkınmada Öncelikli Yöreler (KÖY) ve Kurumsal Sosyal Sorumluluk (KSS) gibi uygulamalarda Türkiye'de uygulanmıştır (Sarıca, 2001, s. 154-204).

1990’lı yıllarda bölgesel kalkınma ajanslarına yönelik ilk uygulamalar Türkiye'de uygulanmaya konulmuştur. Türkiye'de başlayan bu sürecin asıl amacı; AB'ye katılma sürecini hızlandırmak ve içsel kalkınma dinamiklerini harekete geçirmektir. Fakat bu örneklerin çoğu proje aşamasında kalmış veya uygulamanın başlangıcında çıkan sorunlar sebebiyle sona ermiştir (Berber ve Çelepçi, 2005, s. 150).

BKA'ları ciddi anlamda ilk kez Türkiye, AB'ye aday üyeliğinin tescil edildiği 1999 yılında gerçekleşen Helsinki Zirvesi'nden sonra ele almıştır. Avrupa Birliği Komisyonu tarafından hazırlanmış olan "Katılım Ortaklığı Belgesi (KOB)" ile orta vadede yapılması gereken düzenlemeler arasında yer alan BKA'ları oluşturmak için yasal düzenleme işlemleri başlatılmıştır (Hasanoğlu ve Aliyev, 2006, s. 81).

Yapılan düzenlemeler ile NUTS sistemi olarak bilinen kısa vadede istatistiksel bölgeleri 22 Eylül 2002 tarihli Bakanlar Kurulu Kararı ile kabul edilmiştir. 2003 yılına gelindiğinde Katılım Ortaklığı Belgesi'nde, AB'ye katılım öncesi mali destekli mali programlardan yararlanabilmek için BKA'ların kurulması öngörülmüştür. $\mathrm{Bu}$ süreç içerisinde "5449 sayılı Kalkınma Ajansların Kuruluşu Koordinasyonu ve Görevleri Hakkındaki Kanun" gündeme gelmiş ve 25 Ocak 2006 tarihinde kabul edilerek, 08 Şubat 2006 tarihinde resmi gazetede yayınlanarak yürürlüğe girmiştir (Soyak, 2005, s. 3-4). 


\section{Araşturmanın Yöntemi}

Veri toplama arac1 olarak hazırlanan anket formu, KUDAKA'dan 2011 y1lında destek alan, Erzurum, Erzincan ve Bayburt illerinde faaliyet gösteren 44 firmaya uygulanmıştır. Çalışmada gerçek durum tespiti yapılmış ve hedeflenen tüm firmalara ulaşıldığı için detaylı bir istatistikî analize gerek duyulmamış olup anket sonuçları grafiklerle ilgili bölüm başlıkları altında açıklanmıştır.

\section{Araştırmada Bulunan Bulgular}

8 Şubat 2006 Tarih ve 26074 sayılı Resmi Gazete'de 5449 sayılı “Kalkınma Ajanslarının Kuruluşu, Koordinasyonu ve Görevleri Hakkında Kanun" ile Türkiye'de kalkınma ajanslarının kuruluş süreci resmen başlamıştır. 26 Düzey 2 Bölgesi'nde 81 ili kapsayacak şekilde kurulan kalkınma ajansları; ulusal düzeyde Kalkınma Bakanlığı'nın koordinasyonunda ve İBBS (İstatistikî Bölge Birimleri Sınıflandırması) esas alınarak oluşturulmuştur. 22.11.2008 tarih ve 27062 sayılı Resmi Gazete'de yayımlanan Bakanlar Kurulu Kararı ile Erzincan, Erzurum ve Bayburt illerinden oluşan TRA1 Bölgesinde Kuzeydoğu Anadolu Kalkınma Ajansı kurulmuştur (Kudaka, 2018, s. 6).

2011 y1lında uygulanan "Küçük ve Orta Büyüklükteki İşletmeler (KOBİ)" Mali Destek Programının Toplam Bütçesi 11 Milyon TL olup; 21'i Erzurum, 18'i Erzincan ve 5'i ise Bayburt ilinden olmak üzere toplam 44 işletme desteklenmiştir.

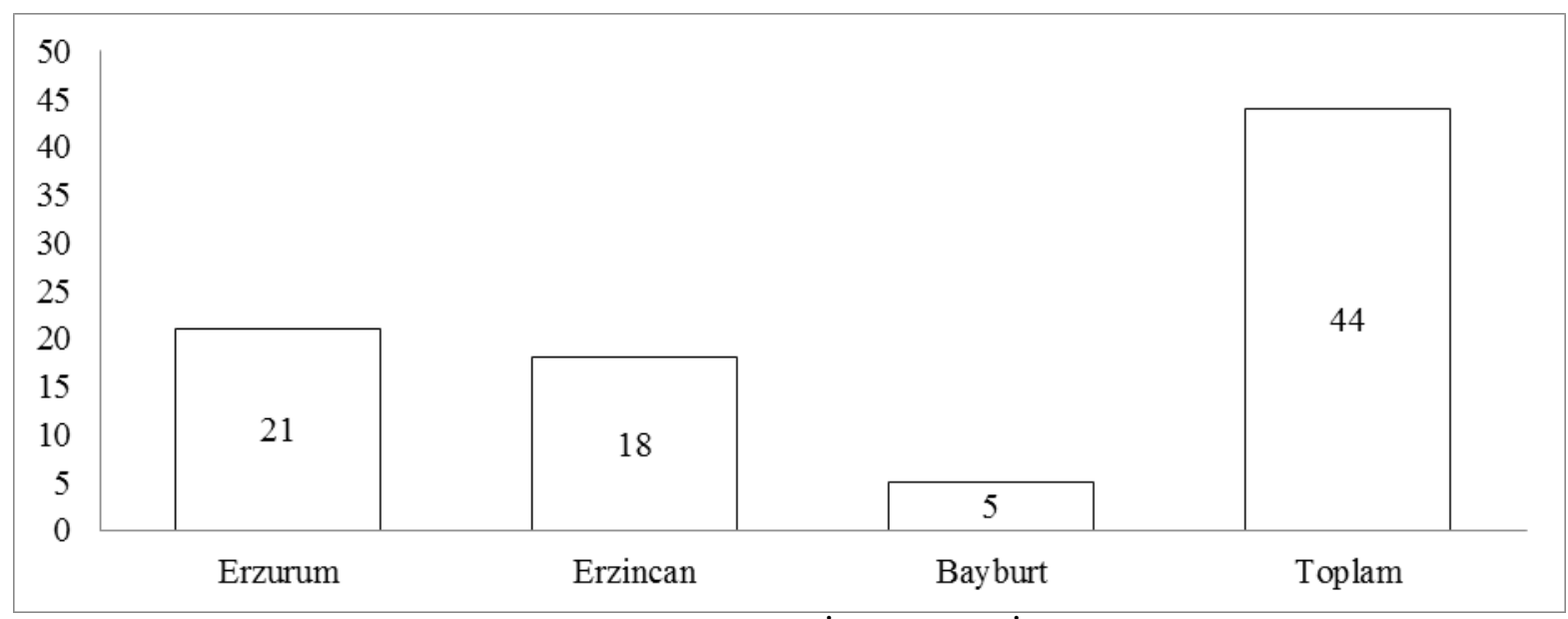

Grafik 1: 2011 Yılında Desteklenen İşletmelerin İllere Göre Dağılımı

Grafik 2'ye göre 2011 y1lında işletmelere verilen mali desteğin; 2,1 Milyon TL Gıda ve Yem Ürünleri İmalatına (11), 1,7 Milyon TL Diğer Metalik Olmayan Mineral Ürünleri İmalatına (9), 886,7 Bin TL Fabrikasyon Metal Ürünleri İmalatına (4), 882,4 Bin TL Mobilya İmalatına (5), 626,9 Bin TL Atığın Toplanması, Islahı ve Bertaraf Faaliyetleri; Maddelerin Geri Kazanımına (1), 436,9 Bin TL Madencilik ve Taş Ocakçılığına (2), 314,1 Bin TL Kauçuk ve Plastik Ürünleri İmalatına (2), 281,2 Bin TL Kayıtlı Medyanın Basılması ve Çoğaltılmasına (3), 258,2 Bin TL Konaklama ve Yiyecek Hizmetleri Faaliyetlerine (3), 234,6 Bin TL Kimyasalların ve Kimyasal Ürünlerin İmalatına (1), 84,6 Bin TL Başka Yerde Sınıflandırılmamış Makine ve Ekipman İmalatına (1), 30,9 Bin TL Tarıma (1) ve 24,3 Bin TL Tekstil Ürünleri İmalatına (1) ayrıldığı görülmektedir. 


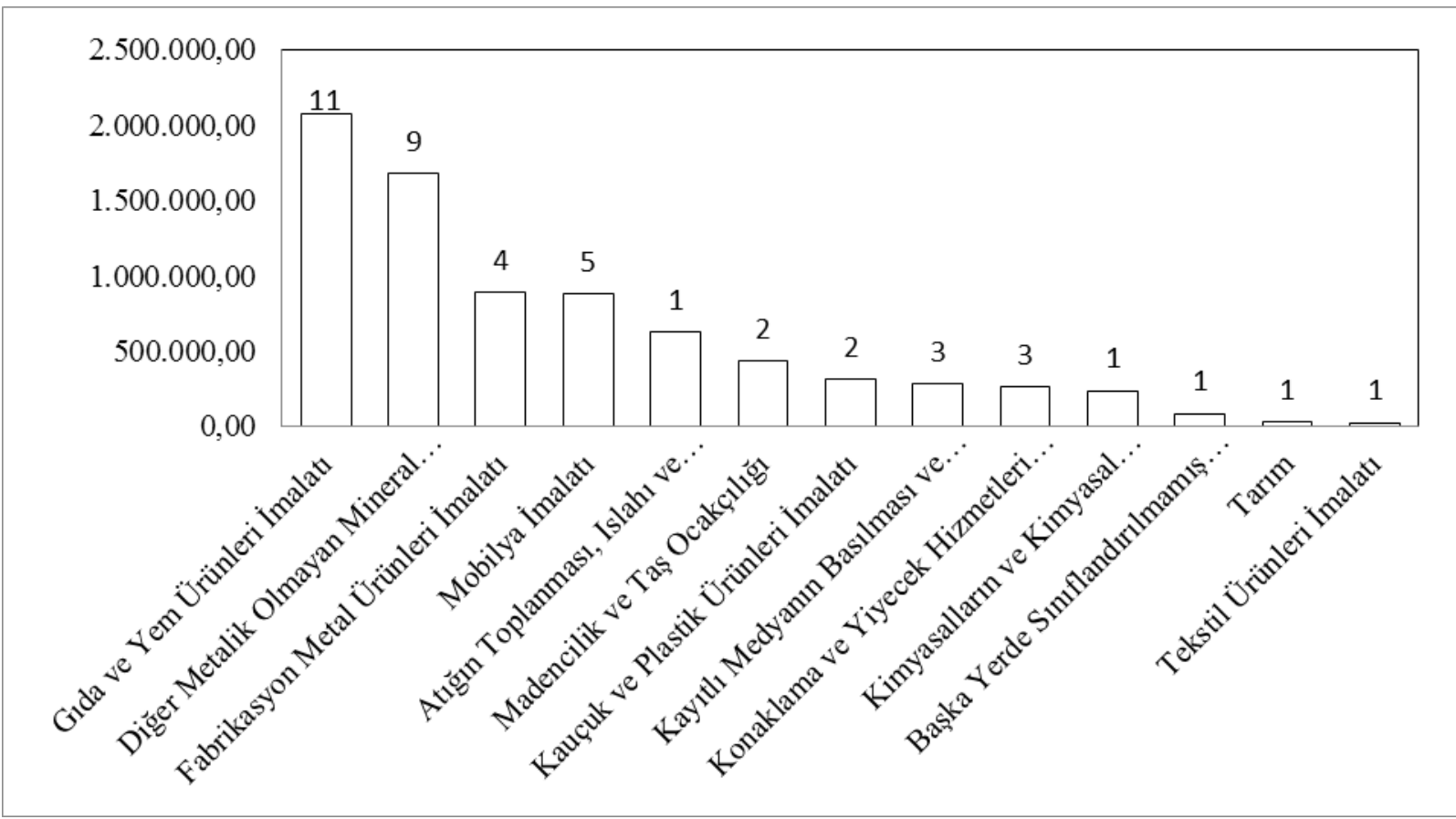

Grafik 2: 2011 Y1lında Ajans Tarafından Desteklenen İşletmelerin Faaliyet Gösterdikleri Sanayi Dallarına Göre Destek Miktarları

2011 yılında ajansın destek verdiği işletmelere; “işsletme olarak ne üretmektesiniz" diye sorulmuştur. 2011 yılında destek alan işletmelerin; \%47'si mal ve hizmeti birlikte üretmekte, \%38'i bitmiş ürün üretmekte, \%25'i hammaddeyi satın almakta, \%16's1 yarı mamul madde üretmekte, \%13'ü hammadde üretmekte, \%6'sı yarı mamul maddeyi satın almakta ve \%6'sı ise bitmiş ürünleri satın alıp pazarladıklarını ifade etmişlerdir. Bu durum Grafik 3'de gösterilmiştir.

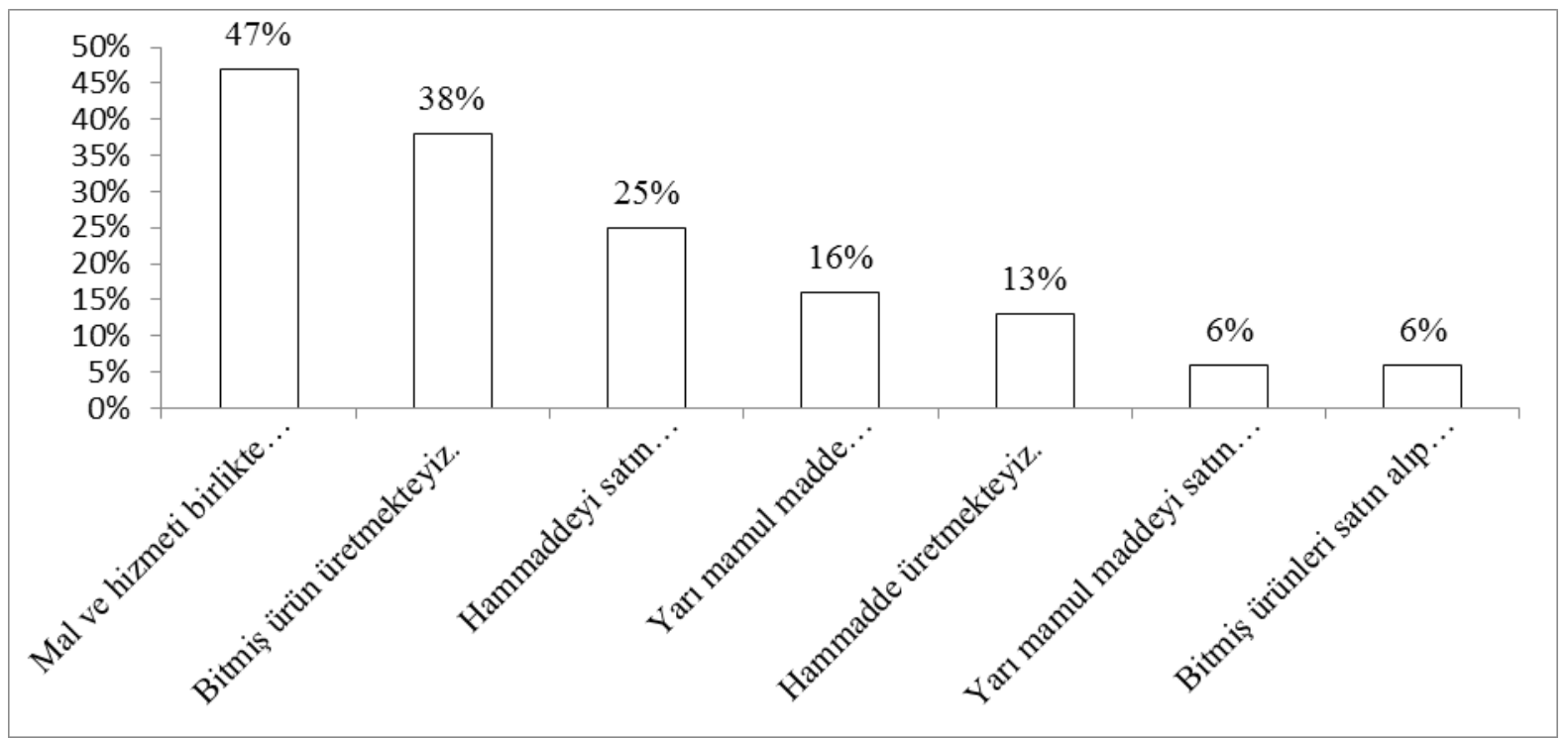

Grafik 3: 2011 Y1lında Ajans Tarafından Desteklenen İşletmelerin Üretim Şekilleri

2011 yılında ajansın destek verdiği işletmelere; “işsletmeniz üretim için gerekli olan hammadde ve yart mamulü nereden tedarik ettiği” sorulmuştur.

2011 y1lında destek alan işletmelerin üretim için gerekli olan hammadde ve yarı mamulü illere göre nereden tedarik ettiğine bakıldığında, Erzurum ilindeki işletmelerin; \%38'i il içinden, \%42'si bölge içinden (Erzurum-Erzincan-Bayburt), \%57'si yurt içinden ve \%14'ü ise yurt dişından; Erzincan ilindeki işletmelerin; \%56's1 il içinden, \%17'si bölge içinden (Erzurum-Erzincan-Bayburt) ve \%61'i ise yurt 
içinden; Bayburt ilinde ise işletmelerin; \%60'1 il içinden ve \%80'i ise yurt içinden tedarik ettiği ifade etmişlerdir. İlgili grafik incelendiğinde sadece Erzurum İlinde faaliyet gösteren işletmelerin hammadde ve yarı mamulün bir kısmını yurt dışından ithal ettiği görülmektedir.

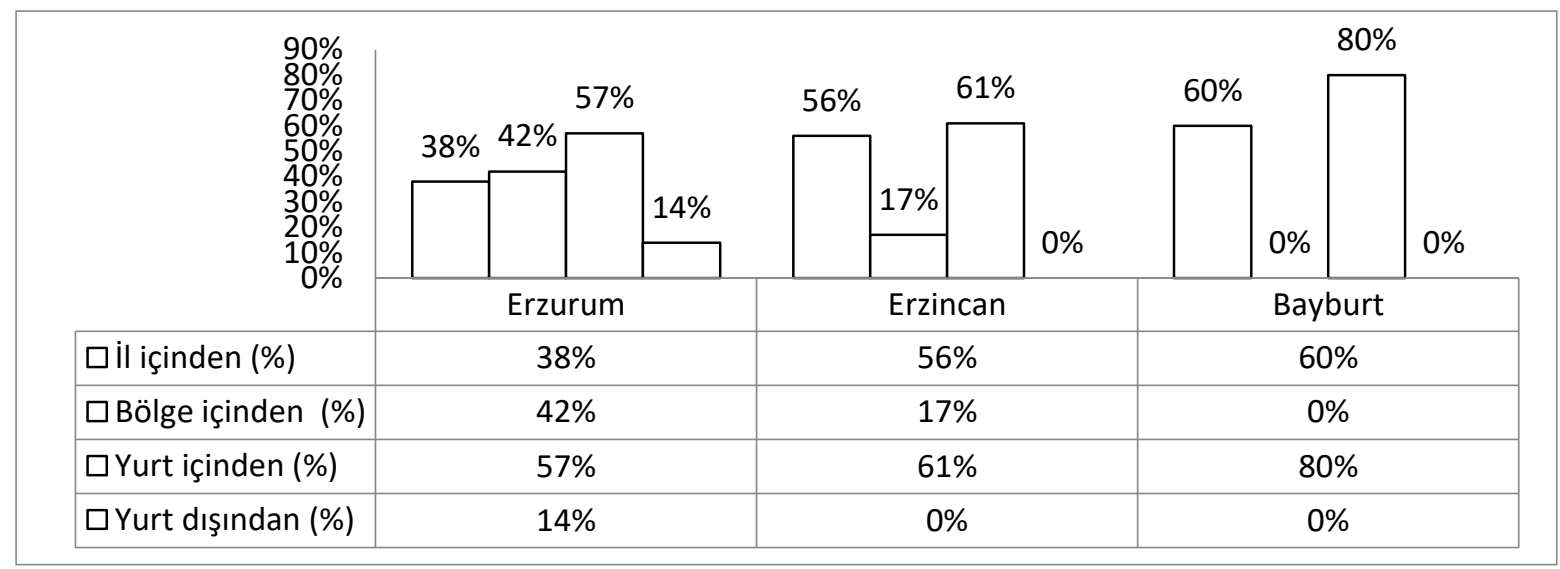

Grafik 4: 2011 Yılında Ajans Tarafından Desteklenen İşletmelerin Gerekli Olan Hammadde ve Yarı Mamulü Nereden Tedarik Ettikleri

İşletmelere "Proje ile birlikte ürün tedarikçi sayısında artış olup olmadı̆̆ı" sorulmuştur.

Grafik 5 incelendiğinde 2011 yılında destek alan işletmelerin; \%82'sinin ürün tedarikçileri sayısında artış olduğu, \%18'inde ise artış olmadığı görülmektedir. İşletmelerin illere göre ürün tedarikçi sayısında artış olup olmadığına bakıldığında ise Erzurum ilinde \%85'inde artış olduğu, \%15'inde artış olmadığı; Erzincan ilinde \%84'ünde artı̧̧ olduğu, \%16'sında artış olmadığı ve Bayburt ilinde ise \%60'ında artı̧̧ olduğu, \%40'ında ise artış olmadığı görülmektedir.

Proje ile birlikte ürün tedarikçisi sayısında artışoldu mu?

Grafik 5: 2011 Yılında Ajans Tarafından Desteklenen İşletmelerin Ürün Tedarikçisindeki Yüzdelik (\%) Artış

"Proje ile birlikte kullandığını hammadde ve yarı mamul miktarında artış olup olmadı̆̆ı" sorulmuştur.

2011 yılında destek alan işletmelerin; \%86'sında hammadde ve yarı mamul miktarında artış olduğu, \%14'ünde ise artış olmadığı görülmektedir. İşletmelerin illere göre hammadde ve yarı mamul miktarında artış olup olmadığına bakıldığında, Erzurum ilinde \%95'inde artış olduğu, \%5'inde artış olmadığı; Erzincan ilinde \%89'unda artış olduğu, \%11'inde artış olmadığı ve Bayburt ilinde ise \%100'ünde artış olduğu görülmektedir. 


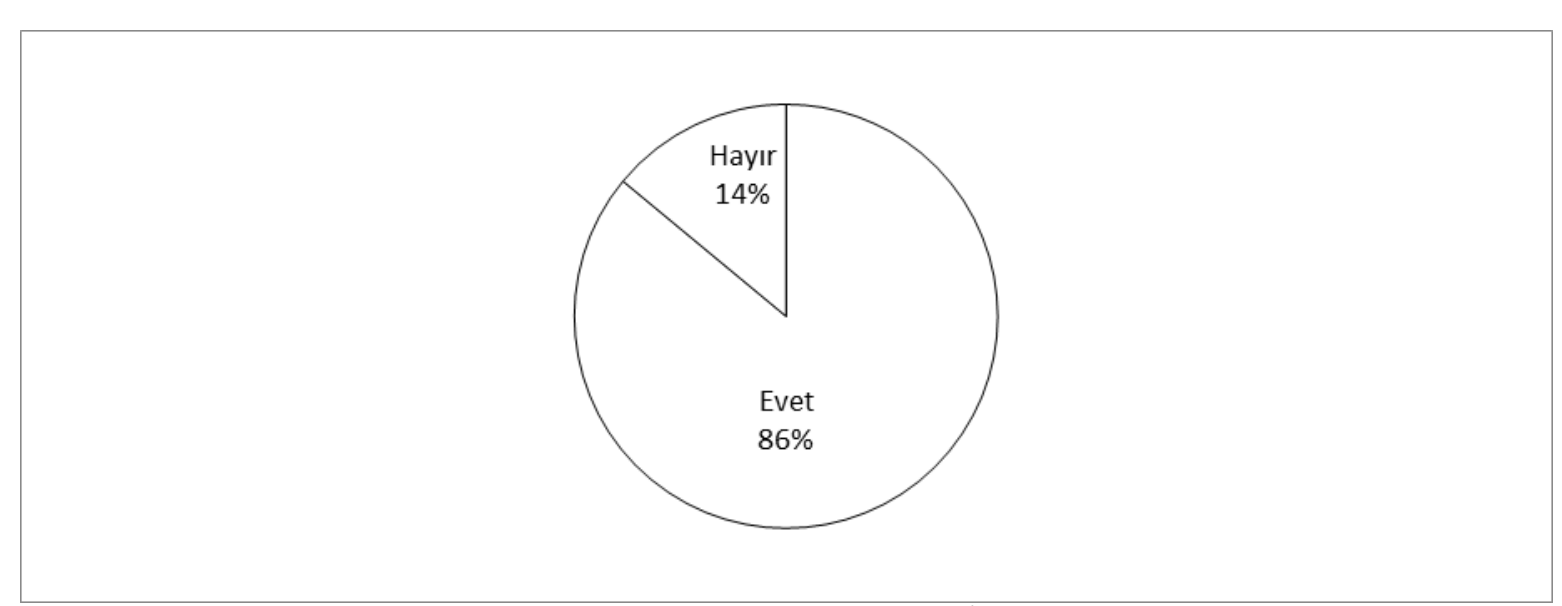

Grafik 6: 2011 ve 2013 Yılında Ajans Tarafından Desteklenen İşletmelerin Hammadde ve Yarı Mamul Miktarındaki Yüzdelik (\%) Artış

Ajans tarafindan desteklenen işletmelere; "proje ile birlikte başka işletmelere girdi olarak sattığını ürünlerde artış olup olmadı̆̆ı” sorulmuştur.

Grafik 7'de gösterildiği gibi; 2011 yılında destek alan işletmelerin \%72'sinin girdi olarak sattığı ürünlerde artış olduğu, \%28'inde ise artış olmadığ 1 görülmektedir. Proje ile birlikte başka işletmelere girdi olarak sattığınız ürünlerde artış olup olmadığının illere göre dağılımına bakıldığında, Erzurum ilinde \%67'sinde artış olduğu, \%33'ünde artış olmadığı; Erzincan ilinde \%89'unda artış olduğu, \%11'inde artış olmadığı ve Bayburt ilinde ise \%40'ında artış olduğu, \%60'ında ise artış olmadığı görülmektedir.

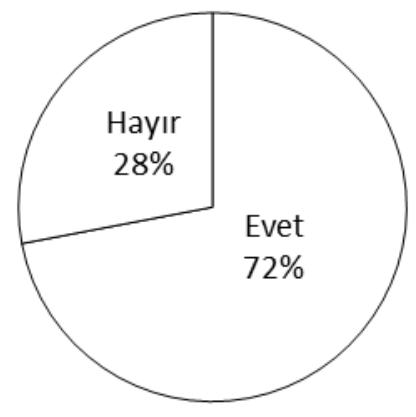

Grafik 7: 2011 Yılında Ajans Tarafından Desteklenen İşletmelerin Proje ile Birlikte Başka İşletmelere Girdi Olarak Sattıkları Ürünlerdeki Yüzdelik (\%) Artış

Ajans tarafindan desteklenen işletmelere; "proje ile birlikte üretim miktarında artış olup olmadiğı ve artış olan üretimin kaynă̆ l” sorulmuştur.

2011 yılında destek alan işletmelerin; \%98'inin üretim miktarında artış olduğu, \%2'sinde ise artış olmadığı görülmektedir. Ajans tarafından desteklenen 44 işletmenin üretim miktarındaki artışının kaynaklarına bakıldığında; 39 işletmede alınan yeni makine ve ekipmanlar, 29 işletmede pazarın genişlemesi, 28 işletmede çalışan sayısında artış olmasından, 27 işletmede tanıtım ve markalaşma faaliyetlerinden, 12 işletmede alınan eğitimler ve 11 işletmede katılım sağlanan fuar ve organizasyonlar olarak belirttikleri Grafik 8'de gösterilmiştir. 2011 yılındaki proje ile birlikte üretim miktarında artış olan alanların kaynağına bakıldığında ön plana çıkanlar ise; alınan yeni makine ve ekipmanlar, pazarın genişlemesi, çalışan sayısında artış ve tanıtım ve markalaşma faaliyetlerinde olduğu görülmektedir. 


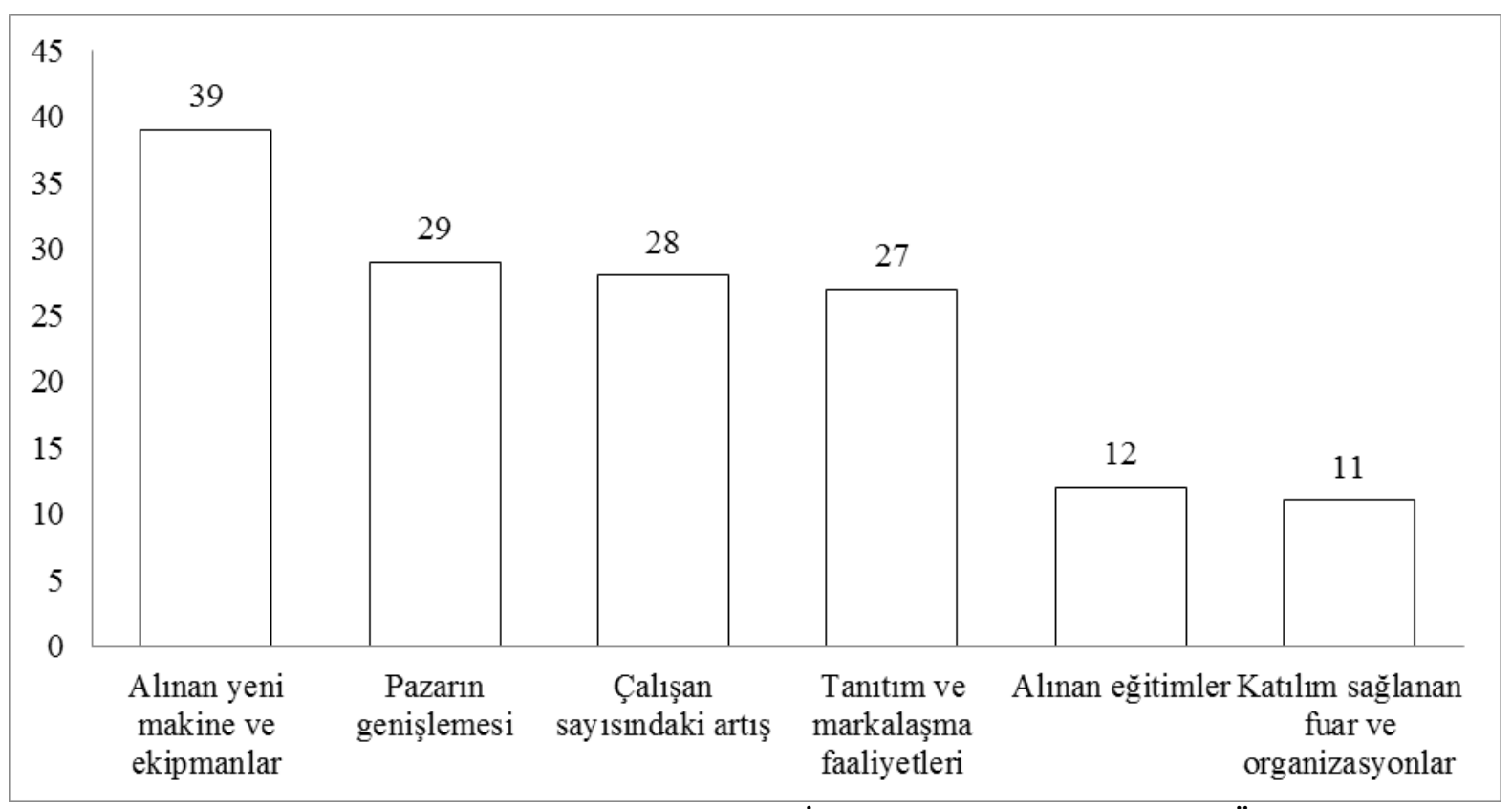

Grafik 8: 2011 Yılında Ajans Tarafından Desteklenen İşletmelerin Proje ile Birlikte Üretim Miktarında Artış Olan Alanları

Ajans tarafından desteklenen işletmelere "şu an itibariyle ürettiğiniz ürünleri hangi pazarlara satmakta olduklart" sorulmuştur.

Grafik 9'da 2011 yılında destek alan işletmelerin illere göre sattıkları ürünleri hangi pazarlara sattıklarına bakıldığında, Erzurum ilindeki işletmelerin; \%80'i il içinde, \%71'i bölge içinde (Erzurum-ErzincanBayburt), \%67'si yurt içinde ve \%24'ü ise yurt dışındaki pazarlara satıs yapmaktadır. Erzurum ilinde yurtdışındaki pazarlara satış yapan işletme sayısı 5'tir. Bu sonuçlara bakıldığında, Erzurum ilindeki işletmelerin satış yaptıkları pazarlar; il içinde, bölge içinde ve yurt içinde yoğunlaşmıştır.

Erzincan ilindeki işletmelerin; \%88'i il içinde, \%66'sı bölge içinde (Erzurum-Erzincan-Bayburt), \%43'ü yurt içinde ve \%11'i ise yurt dışındaki pazarlara satış yapmaktadır. Erzincan ilinde yurtdışındaki pazarlara satış yapan işletme sayısı 2'dir. Bu sonuçlara bakıldığında, Erzincan ilindeki işletmelerin satış yaptıkları pazarlar; il içinde ve bölge içinde yoğunlaşmıştır.

Bayburt ilindeki işletmelerin; \%80'i il içinde, \%20'si bölge içinde (Erzurum-Erzincan-Bayburt) ve \%80'i ise yurt içindeki pazarlara satı̧̧ yapmaktadır. Bayburt ilinde yurtdışındaki pazarlara satış yapan işletme yoktur. Bu sonuçlara bakıldığında, Bayburt ilindeki işletmelerin satış yaptıkları pazarlar; il içinde ve yurt içinde yoğunlaşmıştır.

Ajans tarafından desteklenen işletmelere "projenin sona ermesiyle ürünlerinizi sattığınız pazar büyüklü̈̆̈̈̈nde artış olup olmadı̆̆ ” sorulmuştur.

2011 yılında destek alan işletmelerin; \%86'sının ürünlerini sattığı pazar büyüklüğünde artış olduğu, \%14'ünde ise artış olmadığ 1 görülmektedir. 2011 yılında destek alan işletmelerin illere göre ürünlerini sattıkları pazar büyüklüğünde artış durumuna bakıldığında, Erzurum ilindeki işletmelerin; \%90'ının ürünlerini sattıkları pazar büyüklügünde artış olduğu, \%10'unda ise artış olmadı̆̆ı; Erzincan ilindeki işletmelerin; \%83'ünün ürünlerini sattıkları pazar büyüklüğünde artış olduğu, \%17'sinde ise artış olmadığı; Bayburt ilinde ise işletmelerin; \%80'inin ürünlerini sattıkları pazar büyüklüğünde artış olduğu, \%20'sinde ise artış olmadığı görülmektedir. 2011 yılında destek alan işletmelerin pazarlarının büyük bir kısmını; Karadeniz, Doğu Anadolu, İç Anadolu ve Güneydoğu Anadolu Bölgesi oluşturmaktadır. 


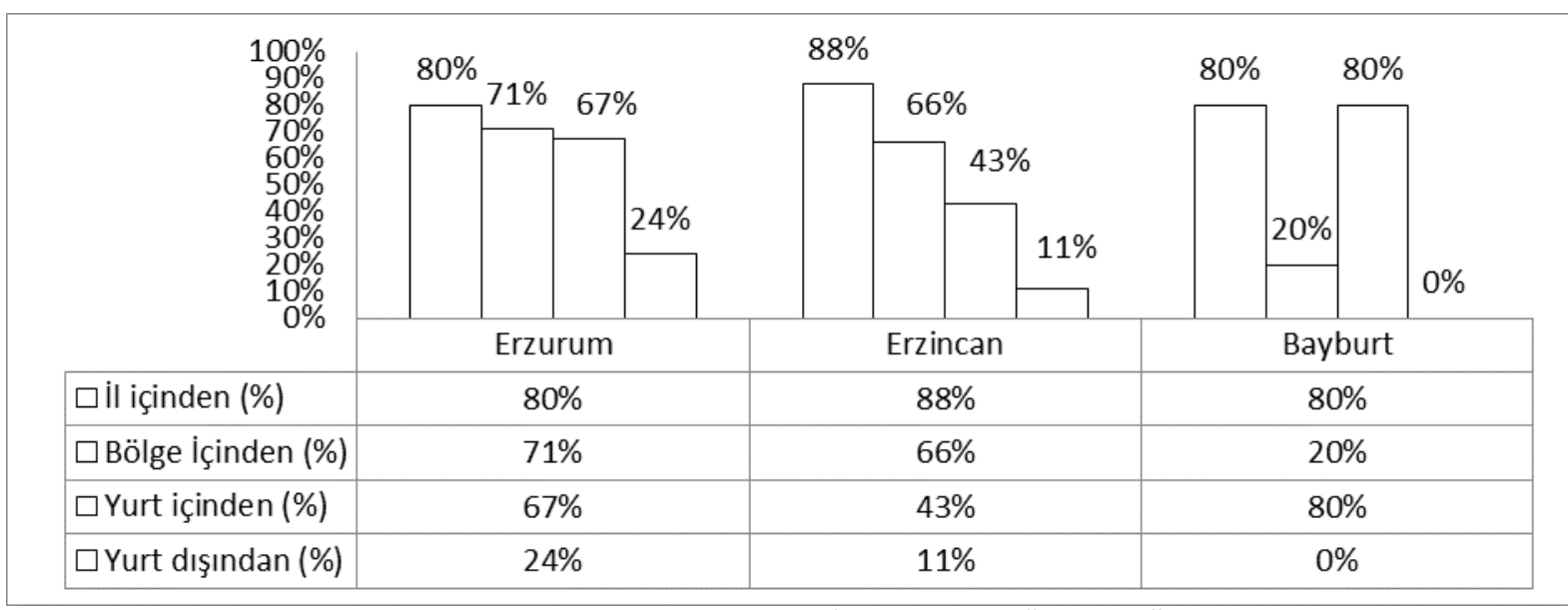

Grafik 9: 2011 Yılında Ajans Tarafından Desteklenen İşletmelerin Ürettiği Ürünlerini Sattıkları Pazarlar

Ajans tarafindan desteklenen işletmelere; "proje kapsamında istihdam sağlayıp sağlamadıkları" sorulmuştur.

2011 yılında destek alan işletmelerin; \%84'ü istihdam sağladığını, \%16'sı ise sağlamadığını belirtmiştir. Erzurum ilinde; 230 kişi, Erzincan ilinde; 85 kişi ve Bayburt ilinde ise 26 kişi olmak üzere toplamda 341 kişinin istihdam edildiği Grafik 10'da gösterilmiştir. Grafik 10'daki verilere göre bölgede 2011 yılında ajans tarafından desteklenen işletmelerin; büyük çoğunluğunun istihdamını artırdığı görülmektedir. Ajansın amaçları doğrultusunda belirlediği öncelikler arasında yer alan istihdamın arttırılması; 2011 yılında verilen desteklerde etkili sonuçlar elde edildiği saptanmıştır.

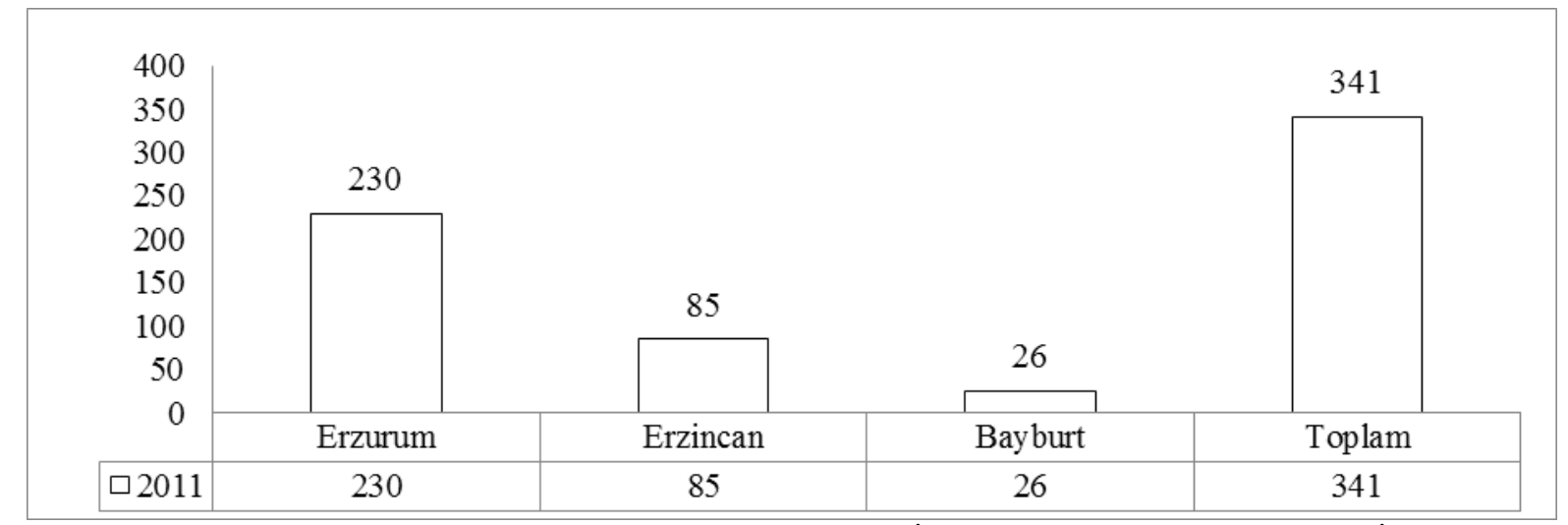

Grafik 10: 2011 Yılında Ajans Tarafından Desteklenen İşletmelerin Proje Kapsamında İstihdam Sağlamas1

İşletmelere "rakiplerinizle klyasladı̆̆ınızda projenin size ne gibi faydaları olduğu” sorulmuştur.

2011 yılında desteklenen işletmelerin; \%62'si rakiplerinin önüne geçmesini sağladığını, \%18'i bölgede rakibinin bulunmadığını, \%11'i rakipleriyle aynı seviyeye (üretim kalitesi, kapasite vb.) gelmesini sağladığını, \%7'si rakiplerine biraz daha yaklaşmasını sağladığını ve \%2'si ise rakiplerine kıyasla bir katk1 sağlamadığını belirttiği Grafik 11'de gösterilmiştir. Bu sonuçlara bakıldığında ajanstan 2011 yılında destek alan işletmelerin; büyük çoğunluğunda proje faydalı olmuştur. 


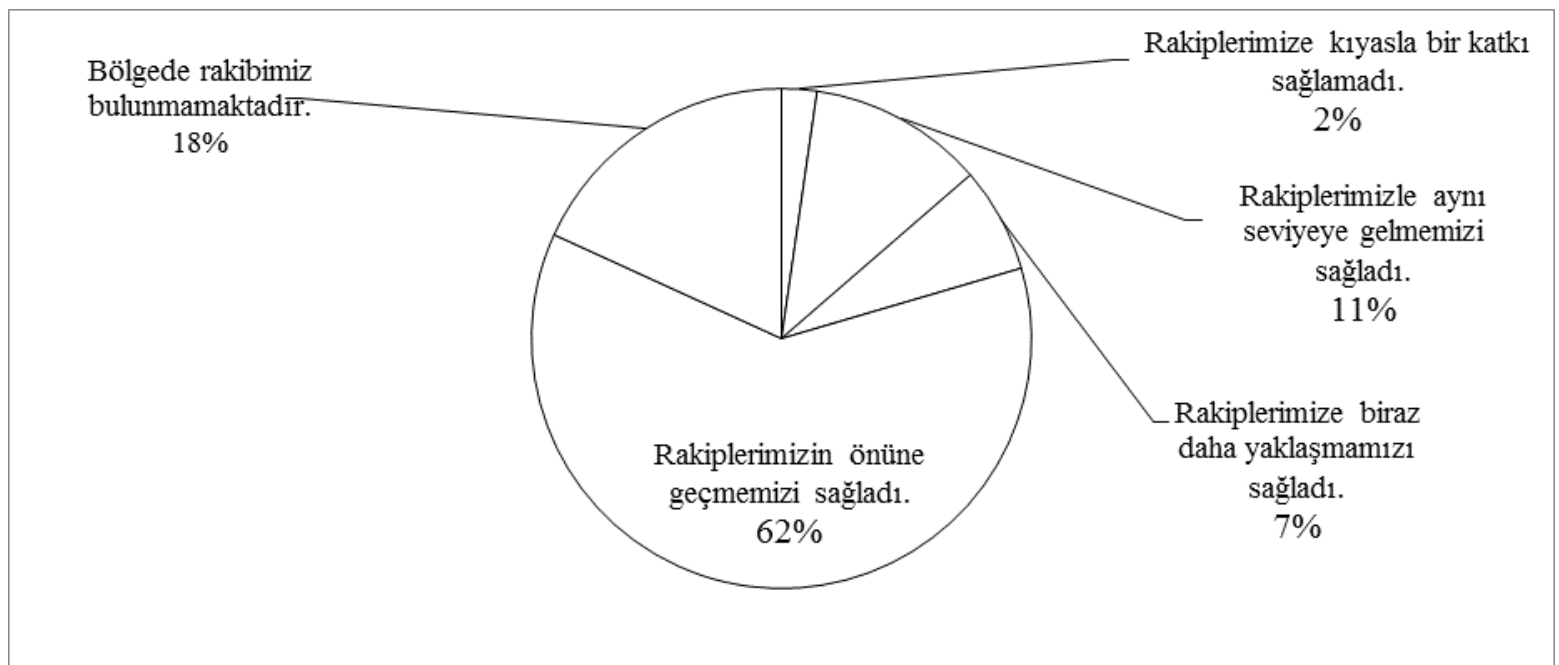

Grafik 11: 2011 Yılında Ajans Tarafından Desteklenen İşletmelerin Proje Faydaları

İşletmelere "ajans tarafindan bu projeniz desteklenmeseydi yine de bu yatırımı gerçekleştirip gerçekleştirmeyecekleri” sorulmuştur.

2011 yılında desteklenen işletmelerin; \%45'i yatırımı daha sonraki bir zamanda yapacağını, \%30'u yatırımı yapamayacaklarını, \%14'ü yatırımı daha küçük ölçekli yapacağını, \%7'si yatırımı aynı şekilde fakat bölge (Erzurum-Erzincan-Bayburt) dışına yapacağını ve \% 4'ü ise yatırımı aynı şekilde yapacağı Grafik 12'de gösterilmiştir. 2011 yılında ajans tarafından verilen destekler olmasaydı, 13 proje yararlanıcısı yatırımını yapamayacağını belirtmiştir. Bu sonuçlara bakıldığında; ajansın projelere desteği olmasa da, çoğu işletme sahibi bu yatırımlarını yapacağı söylenebilir. Ajans tarafından Mali Destek Programı kapsamında verilen desteklerin büyük çoğunluğu, hali hazırda gerçekleştirilecek yatırımlara verildiği görülmektedir.

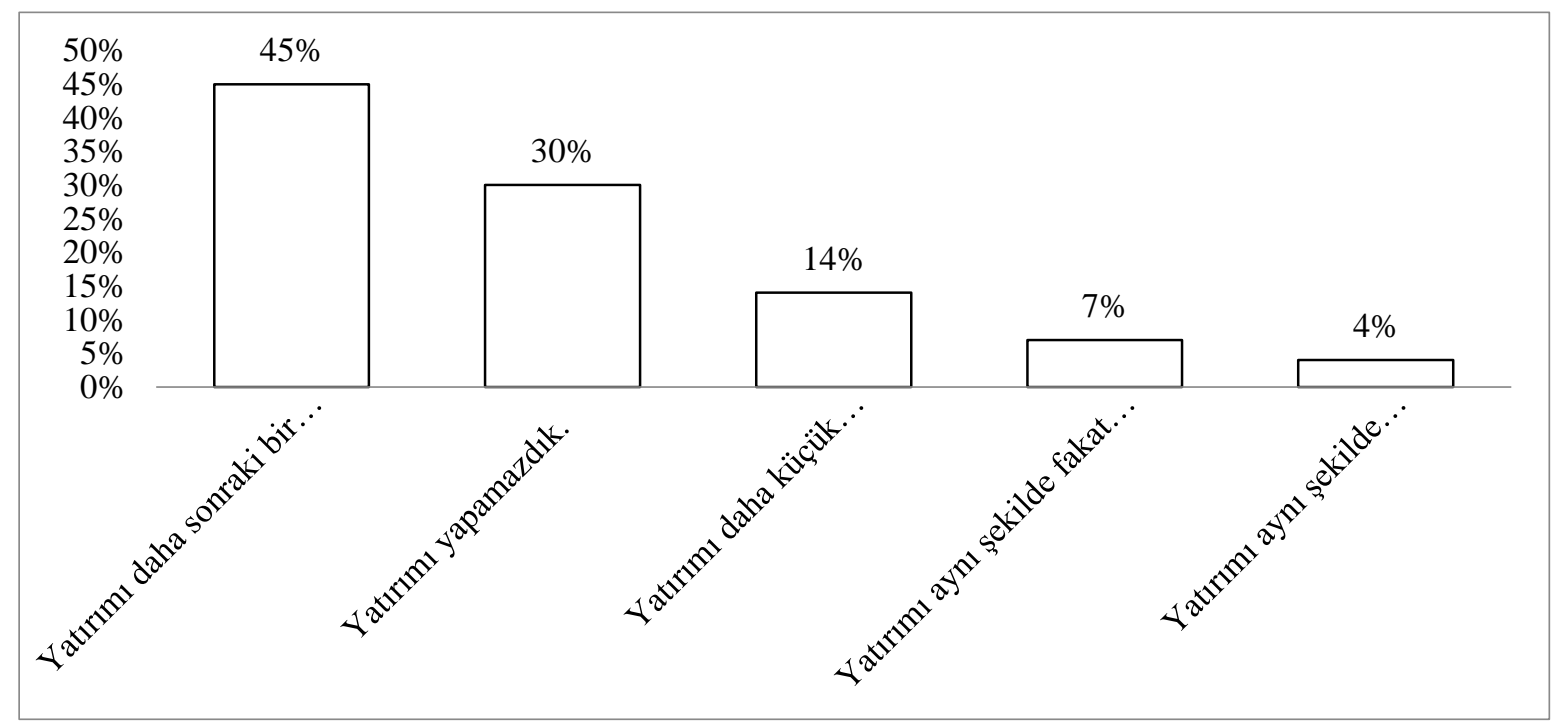

Grafik 12: 2011 Yılında Ajans Tarafından Desteklenen İşletmelerin Ajans Desteği Olmadan Projeyi Gerçekleştirme Durumları

Desteklenen işletmelere "projenizin en önemli çıktıları neler olduğu” sorulmuştur.

2011 yılında ajans tarafindan desteklenen işletmelerin; \%86'sının Üretim kapasitesinin arttı̆̆, \%82'sinin Pazar payının genişlediği, \%73'ünün İşletmesinde personel sayısının arttı̆̆ 1 \% 70'inin Cirosunun arttığı, \%64'ünün Daha kaliteli ürünler üretmeye başladığı, \%61'inin Teknolojik altyapısının güçlendiği, \%59'unun Yeni ürünler üretmeye başladığ 1 , \%57'sinin Üretim maliyetlerinin azaldığ 1 , \%22'sinin İhracat 
faaliyetlerine başladığı ve \%11'inin ise Yönetim sistem/imtiyaz hakkı (ISO, OHSAS, HACCP, TSE, CE, Patent vb.) belgelerine sahip olunduğu projenin en önemli çıktıları olarak Grafik 13'de gösterilmiştir.

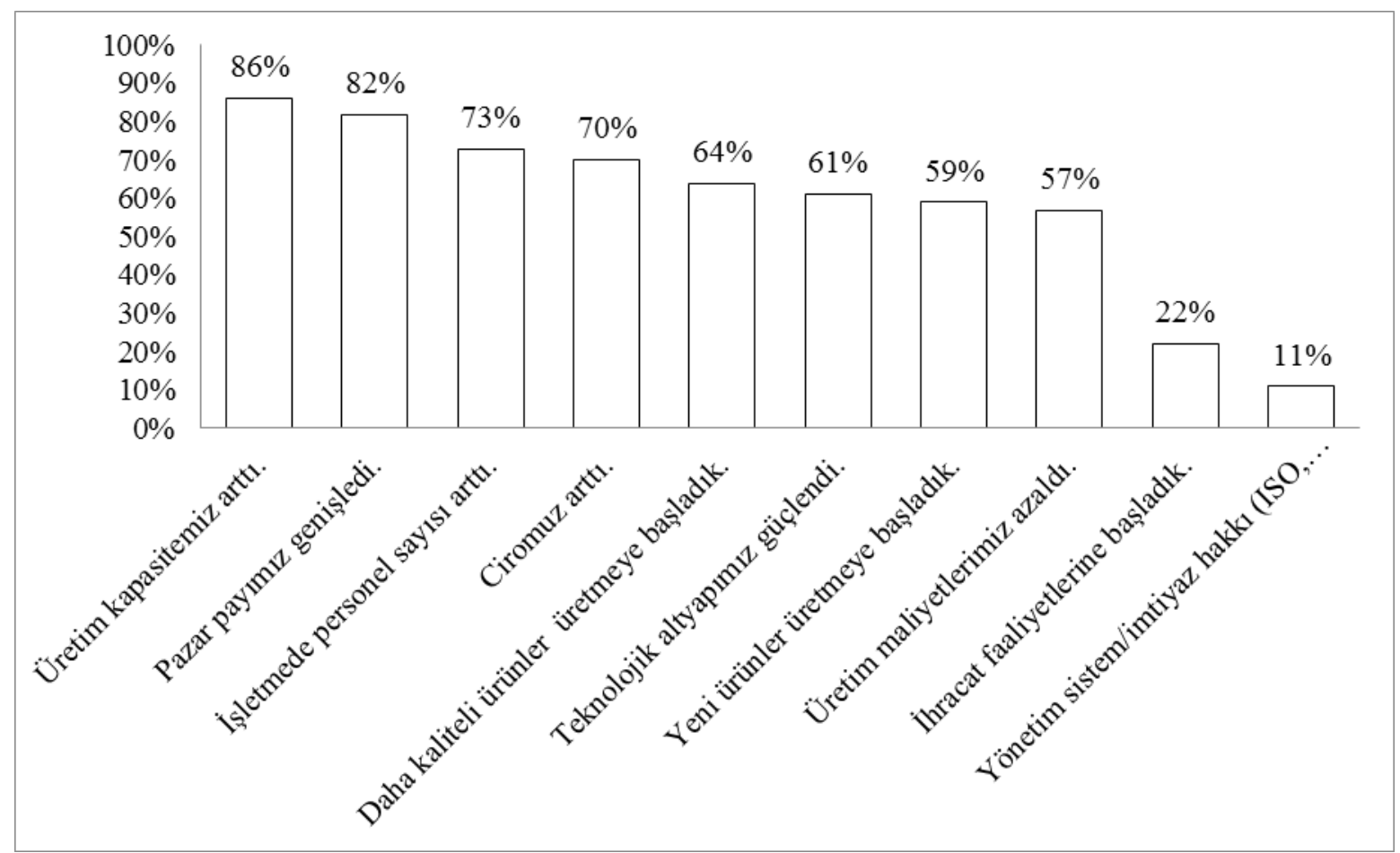

Grafik 13: 2011 Yılında Ajans Tarafından Desteklenen İşletmeler İçin Projenin En Önemli Çıktıları

2011 yılında destek alan işletmelerin; \%68'i ajans tarafindan istenen teminat tutarı gerekli ve makul olduğunu, \%59'u projelere verilen ön ödeme tutarı yeterli olduğunu ve \%43'ü de proje kapsamında verilen hibe miktarı oranı (\%50) yeterli olduğunu belirttiği Grafik 14'de gösterilmiştir. 2011 yılında proje kapsamında desteklenen işletmelerin \%45'i verilen hibe miktarı oranı (\%50) yeterli olmadığını belirtmiştir. Bu sonuçlara bakıldığında; ajans tarafindan yapılan ödemeler için olumsuz herhangi bir görüş yoktur. İşletmelerin verilen destek tutarlarının yetersiz olduğunu belirtmeleri ise refleks haline gelmiş her zaman şikâyetçi oldukları durumdur.

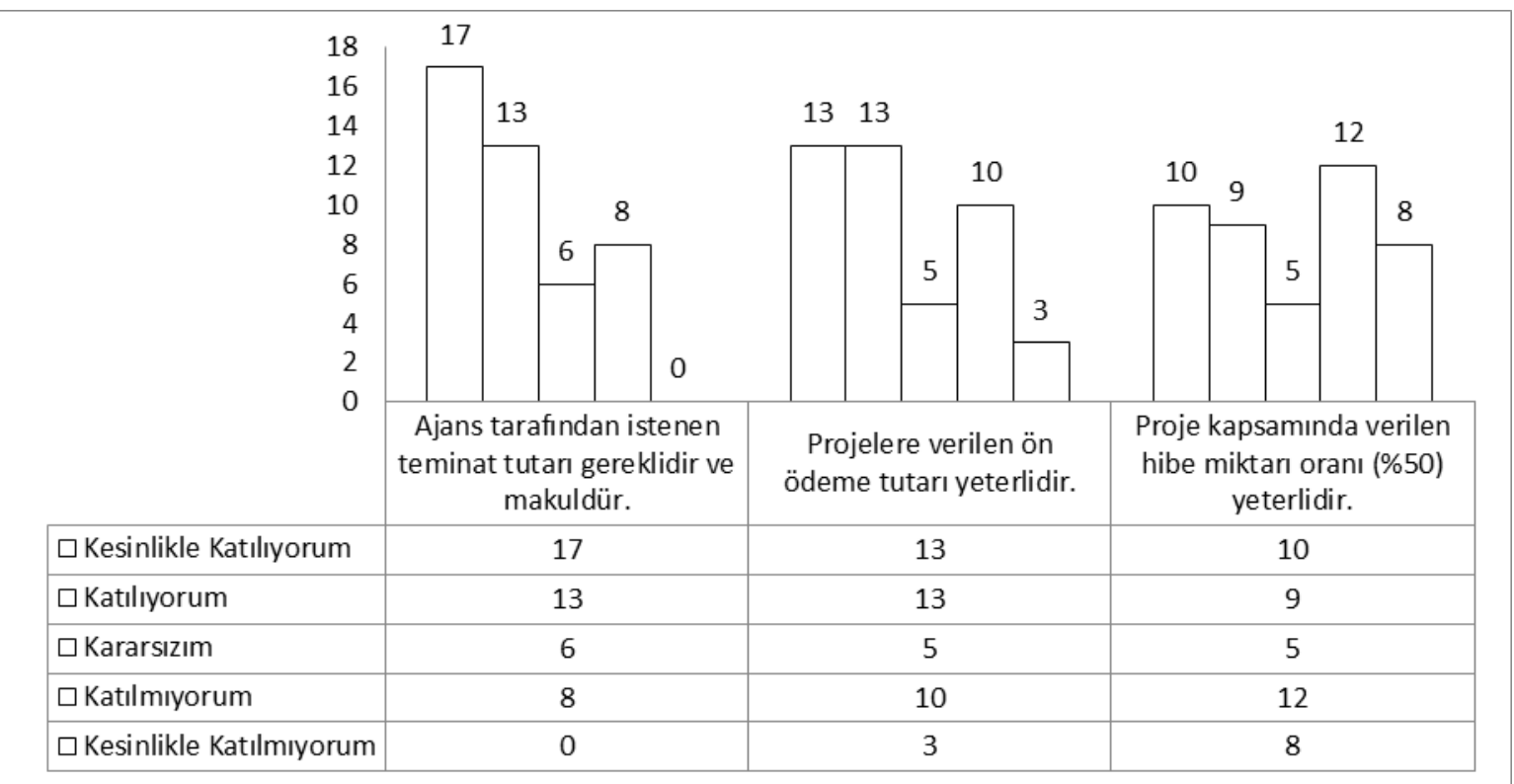

Grafik 14: 2011 Yılında Ajans Tarafından Desteklenen İşletmelerin Proje Ödeme Süreçlerine İlişkin Görüşleri 


\section{DEĞERLENDIRME VE SONUÇ}

Kuzeydoğu Anadolu Kalkınma Ajansı (KUDAKA); Türkiye'de kurulan 26 ajans içinde, Erzincan, Erzurum ve Bayburt illerini kapsayan ve faaliyet gösteren bölgesel kalkınma ajanslarından biridir. İlk kez 2010 yılında KOBİ Mali Destek Programı kapsamında işletmelere destek vermiştir. 2010-2016 yılları arasında Mali Destek Programı kapsamında; ajansın desteklere ayırdığı miktar 72,6 Milyon TL olmuştur. Mali Destek Programına bu yıllar arasında 1394 proje başvurusu yapılmış olup, 354 proje yararlanıcısı ile sözleşme imzalanmıştır.

Kuzeydoğu Anadolu Kalkınma Ajansı'nın (KUDAKA); 2011 yılında Toplam Bütçesi 11 Milyon TL olarak gerçekleşmiştir. KOBİ Mali Destek Programlarının etki değerlendirme sonuçlarına bakıldığında;

- 2011 yılında uygulanan KOBİ Mali Destek Programı kapsamında; projelerin eş finansman kaynağı ile yaklaşık 23 Milyon TL'lik yatırım yapılmıştır.

- 2011 y1lında destek alan 44 işletmenin; \%98'inin üretim miktarında artış olduğu, \%2'sinde ise artış olmadığı görülmektedir. Sadece 1 işletme üretiminde herhangi bir artış olmadığını belirtmiştir. 2011 yılındaki proje ile birlikte üretim miktarında artış olan alanların kaynağına bakıldığında ön plana çıkanlar ise; alınan yeni makine ve ekipmanlarda, pazarın genişlemesi, çalışan sayısında artış ve tanıtım ve markalaşma faaliyetlerinde olduğu görülmektedir.

- 2011 yılında destek alan işletmelerin; \%86'sının ürünlerini sattı̆̆ pazar büyüklügünde artış olduğu, \%14'ünde ise artış olmadığı görülmektedir.

- 2011 yılında destek alan işletmelerin illere göre ürünlerini sattıkları pazar büyüklüğünde artış durumuna bakıldığında, Erzurum ilindeki işletmelerin; \%90'ının ürünlerini sattıkları pazar büyüklüğünde artış olduğu, \%10'unda ise artış olmadığ1; Erzincan ilindeki işletmelerin; \%83'ünün ürünlerini sattıkları pazar büyüklüğünde artış olduğu, \%17'sinde ise artış olmadığı; Bayburt ilinde ise işletmelerin; \%80'inin ürünlerini sattıkları pazar büyüklüğünde artış olduğu, \%20'sinde ise artış olmadığı görülmektedir. 2011 yılında destek alan işletmelerin pazarlarının büyük bir kısmını; Karadeniz, Doğu Anadolu, İç Anadolu ve Güneydoğu Anadolu Bölgesi oluşturmaktadır.

- 2011 yılında destek alan işletmelerin; \%84’ü istihdam sağladığını belirtmiştir. Erzurum ilinde; 230 kişi, Erzincan ilinde; 85 kişi ve Bayburt ilinde ise 26 kişi olmak üzere toplamda 341 kişi istihdam edilmiştir.

- 2011 y1lında destek alan işletmelerin; \%70’i personel almayı düşündüklerini ifade etmiştirler. Erzurum ilinde; 326 kişi, Erzincan ilinde; 115 kişi ve Bayburt ilinde ise 8 kişi olmak üzere toplamda 446 kişi personel istihdam etmeyi düşünmektedirler.

- 2011 yılında uygulan KOBİ Mali Destek Programı kapsamında; ajans tarafından desteklenen işletme sahiplerinin büyük çoğunluğu proje uygulama sürecine ilişkin görüşleri olumlu yönde olmuştur. Olumlu sonuçlar elde edilmesindeki en büyük neden ise; işletme danışmalarının büyük bir rol oynamasidir.

- Araştırma sonuçlarına bir bütün olarak bakıldığında 2011 yılında TRA1 bölgesi olarak bilinen Erzurum, Erzincan ve Bayburt illerinde destek alan işletmelerin büyük çoğunluğunda önemli faydalar elde edildiği ve desteklerin bölge ekonomisine önemli oranda bir katkı sağladığı görülmüştür. KUDAKA'nın kuruluşundan itibaren bölgede bulunan işletmelere mali ve teknik destekler vermesi, Ajansın bölgede etkili bir konumda olduğunu göstermektedir. Ajans tarafından KOBİ Mali Destek Programı kapsamında verilen desteklerin; ulusal kalkınma programları ile uyumlu bir şekilde faaliyet göstermesi; gelecekte daha başarılı sonuçlar elde edilmesinde ve bölgeler arası eşitsizliklerin ve dengesizliklerin ortadan kalkmasında etkin bir rol oynayabilir. KUDAKA'nın bölgede yer alan diğer ekonomik aktörlerle birlikte hareket etmesi etkinlik ve verimliliğin de önemli derecede artmasına neden olacaktır. Aynı şekilde ajansın hibe ve destek programlarından yararlanmak isteyen proje yararlanıcılarına; Ar-Ge hizmetleri ve danışmanlık hizmetleri verilmesi, hibe ve destek programlarının doğru yerde, doğru bir şekilde kullanılması açısından önem arz etmektedir. 


\section{KAYNAKÇA}

Akın, S. ve Yıldız, F. (2005). Bölgesel kalkınma ajansları ve Türk tarımına etkileri. Tarım ve Köy İşleri Bakanlığ 1 , Türk Tarım dergisi, 163, 8-44.

Akpınar, R., Taşc1, K. ve Özsan, M. (2011). Teoride ve uygulamada bölgesel kalkınma politikaları. Bursa: Ekin Kitapevi.

Aydemir, C. ve Karakoyun, İ. (2011). Yeni bölgesel kalkınma yaklaşımı ve kalkınma ajansları: Karacadă̆ kalkınma ajansı örneği. Bursa: Ekin Kitapevi.

Cankorkmaz, Z. (2011). Türkiye'de bölgesel kalkınma ajansları ve bu ajanslara yönelik eleştriler. Dokuz Eylül İktisadi ve İdari Bilimler Fakültesi Dergisi, 26(1), 113-138.

Berber, M. ve Çelepçi, E. (2005). Türk bölgesel kalkınma politikalarında yeni arayışlar: Kalkınma ajansları ve Türkiye'de uygulanabilirliği. Doğu Karadeniz Kalkınma Sempozyumu, 149-157.

Çakmak, E. (2006). Yerel ekonomi ve bölgesel kalkınma ajansları. Ankara: İmaj Yayınevi,

Dinler, Z. (1994). Bölgesel iktisat. 4. Basım. Bursa: Ekin Kitapevi.

Dinler, Z. (2005). Bölgesel iktisat. 7. Basım. Bursa: Ekin Kitapevi.

Dura, Y. C. (2007). Dünya uygulamaları bağlamında kalkınma ajanslarının yapısal analizi. Türk İdare Dergisi, 141-171.

Eren, H. ve Cidecigiller, A. (2011). Bölgesel kalkınma ajansları. İstanbul Üniversitesi Hukuk Fakültesi Dergisi, 69(1-2), 391-410.

Gök, A. (2004). Bölgesel kalkınmanın dış ticarete Etkisi ve GAP örneği. Uygur E., Civcir İ. (Ed.) GAP Bölgesinde Dış Ticaret ve Tarım, 75-80.

Hasanoğlu, M. ve Aliyev, Z. (2006). Avrupa Birliği ile bütünleşme sürecinde Türkiye'de bölgesel kalkınma ajansları. Sayıştay Dergisi, 60, 81-103.

Koçberber, S. (2006). Kalkınma ajansları ve sayıştay denetimi. Saylştay Dergisi, 61, 37-55.

KUDAKA (2018). 2018 yll ajans ara faaliyet raporu. Erzurum.

Özen, P. A. ve Özmen, Y. (2010). Türkiye'de bölgesel kalkınmanın yeni örgütleri kalkınma ajanslart: Öğrenen bölgeler perspektifinde AB bölgesel kalkınma ajanslarının gelişimi, mevcut durumu ve Türkiye'nin alacağı dersler. Akgül B., Uzay N. (Ed.). Bursa: Ekim Kitapevi.

Özen, P. A. (2005). Bölgesel kalkınma ajansları. Ankara: TEPAV.

Özer, Y. E. (2008). Küresel rekabet-bölgesel kalkınma ajansları ve Türkiye. Review of Social, Economic \& Business Studies, 9/10.

Sakal, M. (2010). Bölgesel kalkıınma sürecinde bölgesel kalkınma ajansları. İzmir: Altı Nokta Yayınevi.

Sarıca, İ. (2011). Türkiye'de bölgesel gelişme politikları ve projeleri. Akdeniz Üniversitesi IBBF Dergisi, 154-204.

Sert, O. (2012). Bölge, Türkiye'de bölge kavramı ve kalkınma ajanslarının yapısı. Sosyal Bilimler Dergisi, 2(4), 119-146. 
Soyak, A. (2005). Ertelenen 9. kalkınma planı ve Türkiye'de planlamanın geleceği üzerine bir not. Bilim ve Ütopya Dergisi, 136, 3-4.

Taştekin, A. (2018). Türkiye'de bölgesel kalkınma stratejileri ve bölge idareleri. Uluslararası Yönetim Akademisi Dergisi, 1(1), 69-83.

Tuncel, C. O. Ve Bakir, H. (2010). Yenilik Temelli Bir Bölgesel Gelişme Sürecinde Kalkınma Ajanslarının Yeri. İsletme ve Ekonomi Araştırmalar Dergisi, 19-41. 